\title{
AS BELLES INFIDÈLES E OS ROMÂNTICOS ALEMÃES ${ }^{\mathrm{i}}$
}

\section{THE BELLES INFIDÈLES AND THE ROMANTIC GERMAN}

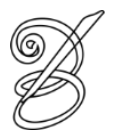 \\ Vanete SANTANA-DEZMANN (USP) ${ }^{\mathrm{ii}}$ \\ Pós-doutoranda \\ Universidade de São Paulo (USP) \\ São Paulo, São Paulo, Brasil \\ seide2003@hotmail.com
}

\begin{abstract}
Resumo: O presente artigo relaciona a ascensão da tradição de tradução de cunho prático e filosófico conhecida como Belles Infidèles, que se estabeleceu na França do século XVII, ao contexto que a possibilitou, ressaltando que sua valorização ocorreu em virtude da necessidade que os franceses sentiam de preservar sua língua e cultura - de certa forma, já estabelecidas e dominantes -, bem como explica por que tal tradição não prosperou entre os tradutores nos estados germânicos.
\end{abstract}

Palavras-chave: História da tradução. Belles Infidèles. Deutschheit.

Abstract: This article relates the rise of the "tradition" of translation of a practical and philosophical character known as Belles Infidèles, which occurred at the seventeenth-century in France, the context that made it possible, noting that his recovery was due to the need that the French felt to preserve their language and culture - more or less already established and dominant - and explains why such a current did not prosper among the translators of the German states.

Keywords: History of translation. Belles infidèles. Deutschheit.

\section{Introdução}

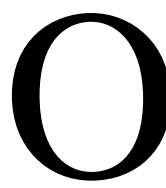

intenso interesse por obras latinas manifesto na França no final do século XV e início do seguinte levou à publicação de uma enorme quantidade de traduções (cf. ZUBER, 1995, p. 22). O traço comum a todas elas foi a desconsideração das características da língua francesa. Uma vez que "estrangeirizava” a língua de chegada, os poetas da Pléiade a tratavam como incapaz de propiciar seu desenvolvimento e, por isso, classificavam-na como atividade literária de menor valor (cf. ibid., p. 23).

Diante da necessidade de estabelecer balizas para a tradução que fizessem com que ela se submetesse às poucas normas que então norteavam o francês, em 1540 Étienne Dolet publicou Manière de bien traduire d'une langue en autre (Modo de bem traduzir de uma língua a outra). De acordo com Joachim du Bellay, porém, a normatização do processo de tradução era mais uma questão de política linguística do que estética. Tal como seus companheiros da Pléiade, ele defendia a criação de obras originalmente escritas em francês e, 
por isso, desprezava as traduções (cf. BALLIU, 1995, p.12). Sendo a tradução inevitável, propunha que o foco recaísse sobre a estética da língua para a qual se traduzia e, neste caso, a tradução como imitação das consagradas formas clássicas seria inútil.

Assim como Dolet, Jacob Amyot (1513-1593, também chamado Jacques Amiot) - um dos mais célebres tradutores franceses, que traduzia inclusive obras gregas, raro à época (cf. ibid., p.13) - preconizava o enriquecimento da língua francesa por meio da criação de palavras e frases que soassem naturais em francês e o uso do estilo e eloquência típicos do francês também nas obras em prosa.

A partir do Renascimento e do Humanismo, a tradução passou a exercer relevante função na constituição das línguas nacionais europeias e na formação de cânones literários nacionais uma vez que o acesso às obras latinas e gregas, anteriormente franqueado apenas aos clérigos, insuflaram-lhe novos conceitos e termos.

Na França, o início do século XVII foi marcado pela fundação da Academia Francesa (1634) e pelos esforços empreendidos pelos homens de Letras no sentido de depurar e codificar a língua nacional francesa. Neste contexto, os tradutores passaram a ocupar posição 90 de destaque e suas traduções ajudaram na compilação dos primeiros dicionários então publicados. Tais tradutores se encontravam, também, entre os principais interessados nas discussões sobre aprimoramento linguístico e estilístico, que, segundo Nicolas Perrot d'Ablancourt (1606-1664), podia ser medido a partir dos três seguintes parâmetros: clareza, concisão e elegância. Ele próprio teria se dedicado a escrever de modo conciso e elegante (cf. DELISLE e WOODSWORTH, 1995, p. 33). Além disso, suas traduções ficaram conhecidas pelo expurgo de concepções e termos que pudessem "chocar" os leitores - orgia e sodomia são exemplos de termos que ele suprimiu dos textos gregos ao traduzi-los. Ele procurava atenuar as diferenças de costumes constatadas entre a cultura apresentada no texto de partida e a francesa; adaptar as regras de comportamento às normas correntes na França de sua época e adaptar o comportamento das personagens ao que considerava condizente com sua posição social (cf. MILTON, 1998, p. 58). Por esta razão, era criticado e acusado de infidelidade ao texto de partida (cf. DELISLE e WOODSWORTH, 1995, p. 33).

Diante da tradução "nada fiel”, dizia-se, que M. d'Ablancourt fizera do Diálogo, de Lucien de Samosate, Gilles Ménage (1613-1692) teceu o seguinte comentário: “eu a chamaria a Belle Infidèle, que era o nome que eu havia dado, quando jovem, a uma de minhas amantes" (apud. DELISLE e WOODSWORTH, 1995, p. 33, tradução minha). Desde então, a expressão "belle infidèle" (em português, "bela infiel") passou a designar as traduções que se 
preocupavam mais com a beleza do texto de chegada do que com o conteúdo e estilo do texto de partida - as "traduções livres" -, que prosperaram, sobretudo, no período compreendido entre os anos de 1625 e 1665 e estiveram no auge entre 1640 e 1650 (cf. ZUBER, 1995, p. V). Nesta época, a tradução foi elevada à categoria de arte e era classificada como gênero literário. A prática de tradução empreendida por M. d'Ablanclourt e seus seguidores acabou dando origem a uma tradição de tradução de cunho prático e filosófico que acabou conhecida como "Belles Infidèles" devido, justamente, ao comentário de Ménage.

O francês clássico, como o conhecemos atualmente, foi estabelecido entre 1600 e 1660 (cf. BALLIU, 1995, p.16). A partir de então, com a publicação da Grammaire générale et raisonnée contenant les fondements de l'art de parler, expliqués d'une manière claire et naturelle (Gramática geral e razoada contendo os fundamentos da arte de falar, explicados de modo claro e natural), de Antoine Arnauld e Claude Lancelot, tematizando a filosofia da linguagem a partir da perspectiva de René Descartes, os tradutores de Port-Royal passaram a dominar a cena, tornando-se mais importantes que os tradutores integrantes da Academia Francesa. O termo "Port-Royal" foi empregado em referência ao mosteiro jansenista de PortRoyal-des-Champs (região em que atualmente se encontra o vilarejo de Saint-Rémy-lèsChevreuse, próxima a Paris), onde eles viviam. Enquanto jansenistas, suas obras - originais, no sentido de "próprias", e traduções - tinham finalidade doutrinal e pedagógica, mas se constituíam também em importantes fontes de reflexões e discussões sobre a língua. Para eles, a arte de traduzir e a arte de escrever caminhavam lado a lado. Traduziam, sobretudo, textos latinos do período clássico e, tal como seus colegas da Academia, expurgavam de suas traduções os termos e conceitos que consideravam passíveis de chocar e desvirtuar seu público leitor.

\section{A tradução, segundo a tradição Belles Infidèles}

Apoiando-se nas concepções de Du Bellay, os tradutores que acabaram por consolidar um modo de traduzir e de pensar sobre a tradução que instauraria a tradição conhecida como “Belles Infidèles” (BALLIU, 1995, p.12) visavam à autonomia linguística amparada por um senso estético próprio que deveria se manifestar inclusive em prosa, mesmo quando tivesse os modelos clássicos como inspiração. O esteticismo exacerbado que ficou conhecido como "bom gosto", característico da língua francesa, passou a determinar o estilo linguístico que os textos escritos em francês - escritos originalmente em francês ou traduzidos - deveriam apresentar (cf. ibid., p.17). Por isso, as traduções empreendidas na França dos séculos XVII e 
XVIII eram uma espécie de "imitação à distância" (cf. ibid., p.17), determinada pela adequação ao estilo local corrente. Assim, adaptando e recriando as obras clássicas no sentido de as tornarem agradáveis ao público alvo, ou seja, guiando-se pelas normas do "bom gosto" dos eruditos e, a partir de 1634, pelas regras de eloquência da Academia Francesa, os tradutores franceses construíram sua literatura clássica. De acordo com Christian Balliu, as traduções mantinham certa "fidelidade estilística dinâmica" e certa "equivalência de efeitos" (cf. ibid., p.17). Para tanto, os procedimentos tradutórios, conforme apresentados por D’Ablancourt (apud. POPPI, 2013, p. 35), resumiam-se a: (i) assumir não ter realizado uma "tradução comum" (traduction régulière); (ii) apontar questões de intraduzibilidade (peculiaridades dos termos gregos que não seriam entendidas fora do contexto); (iii) excluir as comparações do amor (por se tratar de amor homossexual, comum aos gregos e abominável aos costumes franceses), e (iv) excluir os versos referentes a Homero, bem como as "velhas fábulas batidas", os provérbios, exemplos e comparações antiquados, pedantes e sem erudição. Ou seja, em se tratando de tradução, havia que se considerar mais o que era preciso e possível de se dizer em francês na França daquela época (apud. POPPI, 2013, p. 35) do que 92 o que se identificava no texto de partida.

M. d'Ablancourt justificava os procedimentos recomendados apontando que Terêncio, em sua tradução das comédias de Menandro, e Cícero, em sua tradução dos Ofícios, haviam feito exatamente o mesmo. Como argumento em defesa de seus procedimentos, comparava o texto de partida a um belo rosto que, como sempre, contém algo desagradável e os tradutores aos embaixadores, que devem se dobrar aos costumes dos locais onde se encontram:

\begin{abstract}
Assim como nos belos rostos há sempre algo que gostaríamos que não estivesse ali, do mesmo modo, nos melhores autores, há passagens que convêm retocar ou esclarecer, especialmente quando as coisas são feitas somente para agradar; pois então não se pode suportar o mínimo defeito, e se a delicadeza faltar nem que seja por pouco, em vez de agradar, aborrece. [...] As diversas épocas pedem não somente palavras, mas pensamentos diferentes; e os embaixadores têm o hábito de se vestirem à moda do país para onde são enviados, por medo de parecerem ridículos perante aqueles que se esforçam por agradar (apud. POPPI, 2013, p. 35).
\end{abstract}

A tradução dos clássicos se resumia, então, a usar o texto de partida apenas como referência, adotando-se a forma cultivada no momento da tradução e adaptando ou recriando - conforme a necessidade - a linguagem de acordo com as regras das instituições do "bom gosto" e da Academia Francesa. 
Da mesma forma, por motivos estéticos e ideológicos, a Gramática de Port-Royal, como é conhecida entre nós, prescrevia a depuração das obras latinas durante o processo de tradução por meio da exclusão de elementos que se chocassem com a cultura francesa. São célebres os expurgos praticados por Antoine-Isaac, Barão Silvestre de Sacy (1758-1838) em suas traduções em nome da moral, pois, considerando-se a função pedagógica da literatura, acreditava-se que era necessário transmitir os valores da cultura clássica aos educandos, porém seus "vícios" e "imoralidades" não deveriam ser propagados. Assim, recomendava-se que o texto de partida fosse totalmente adaptado às convenções da cultura da língua de chegada, sendo considerada boa a tradução que estivesse formulada de modo mais elegante de acordo com tais convenções - do que o apresentado pelo texto de partida. Os tradutores de Port-Royal, como se pode perceber, não eram os únicos, nem foram os primeiros, a defender e a praticar a adaptação livre do texto de partida à cultura de chegada.

Dentro da tradição Belles Infidèles - conforme praticada pelos "Senhores de PortRoyal" -, coube-lhes a tarefa de estabelecer parâmetros a fim de se evitar que a cultura francesa, tipicamente católica - como os mesmos Senhores - fosse afetada pela cultura pagã veiculada pelas obras latinas e gregas registradas na época anterior ao cristianismo. A obras que deveriam doutrinar e educar seus leitores, não cabia disseminar concepções tão díspares das que defendiam aqueles que as selecionavam e traduziam.

\section{Enquanto isto, do outro lado do Reno...}

O século XVIII se abre na Europa com o estado prussiano se separando do Sacro Império Romano-Germânico. Frederico de Brandenburgo, coroado rei da Prússia em 1701, foi sucedido por Frederico I, o Soldado Rei, a partir de 1713. Neste ano, começava a disputa pela sucessão ao trono da Áustria, que perduraria por oito anos, gerando as Guerras da Silésia, que só chegariam ao fím em 1763. Ao longo deste período, a monarquia austríaca dos Habsburgos, no comando do Sacro Império Romano-Germânico, lutou contra o Reino da Prússia, sob a dinastia dos Hohenzollern, pelo controle da Silésia - parte das atuais República Tcheca e Polônia que se encontra na fronteira com a atual Alemanha. Justamente nesta época, França e Inglaterra se consolidavam enquanto estado-nação, como resultado de um processo que começara a se delinear ao final da Guerra dos Cem Anos (1453), no caso da França, e ao final da Guerra das Rosas (1485), no caso da Inglaterra. Lembremo-nos que o que se convencionou chamar Guerra dos Cem Anos envolve uma série de conflitos armados 
intermitentes entre França e Inglaterra que se estenderam de 1337 a 1453, perfazendo, portanto, cento e dezesseis anos.

O conceito de estado-nação - principal resultado político da Revolução Capitalista gerada pela Revolução Industrial iniciada na Inglaterra nos primórdios do século XVIII assenta-se nos conceitos de estado (sistema constitucional e, simultaneamente, organização que o garante; organização constituída por políticos, burocratas e militares detentores do poder de legislar e tributar e, por fim, ordem jurídica oriunda desta atividade) e de nação (sociedade submetida a um destino comum e capaz de constituir um estado - na acepção moderna - que lhe garanta segurança ou autonomia nacional e desenvolvimento econômico). Estado-nação pode, então, ser definido como unidade político-territorial soberana integrada por uma nação, um estado e um território (porção geográfica delimitada que, gerida por um governo independente dos demais, caracteriza um país) $)^{\mathrm{iii}}$, constituindo-se na forma mais abrangente de organização político-territorial nas sociedades capitalistas industriais. Seus dirigentes, além de objetivarem a segurança do estado, objetivavam também ao desenvolvimento econômico e à disseminação da educação pública (importante para a 94 formação de mão-de-obra qualificada) e da busca pela produtividade entre todos os integrantes do território nacional.

Uma vez que, a partir da Revolução Industrial, definir as fronteiras do mercado nacional passou a ser de extrema relevância, estabelecer-se como estado-nação passou a ser fundamental para o desenvolvimento econômico. A desunião entre os governantes territoriais do Império Germânico, porém, postergara o processo de consolidação de um estado-nação germânico. Até os fins do século XIX, predominava no território do Sacro Império RomanoGermânico a deutsche Kleinstaaterei, ou seja, os pequenos estados localizados naquele território se mantinham independentes, tal que cada um tinha sua própria legislação (Heimatgesetzgebung), com diferentes condições para estabelecimento comercial e desempenho de profissões; diferentes moedas - o que impedia o estabelecimento de um sistema bancário comum -; diferentes sistemas de pesos e medidas - nenhum dos quais, tal como suas moedas, reconhecido no mercado mundial - e limite de estadia para cidadãos oriundos de outros estados, incluindo-se aí estados componentes do próprio território germânico - não havia liberdade de circulação em seu interior nem mesmo para seus cidadãos e o conceito de "cidadania alemã", ou "cidadania germânica", nunca fora aventado (cf. Engels, 1888.). 
Embora o embrião já se encontrasse em gestação, o fato é que, a partir de então, a futura Alemanha perderia a preponderância entre os estados europeus, em parte também em consequência da devastação promovida em sua população, território e finanças pela Peste Negra (1350) e Guerra dos Trinta Anos (1618-1648).

Assim, percebemos que, a partir de uma origem comum - Reino Franco -, os embriões da França e Alemanha cedo se separaram e se distanciaram até o ponto em que, em meados do século XVIII, aquela se encontrava convertida em centro cultural da Europa e Rússia e logo viria a protagonizar uma das principais revoluções do mundo ocidental e caminhar a passos largos para a consolidação de sua hegemonia - frustrada - na Europa, enquanto o Império Germânico permaneceria fragmentado em diversos estados até o final do século XIX. A estes estados germânicos, fragmentados em vários níveis, inclusive em termos culturais, era preciso construir uma noção de identidade nacional, que reuniria os descendentes de diferentes tribos germânicas em torno de uma pátria comum, uma nação unificada - o Império Alemão, que só viria a se estabelecer como estado-nação em 1871.

Vários agentes culturais se apresentaram para cooperar no processo de construção da identidade nacional germânica e seus momentos mais preponderantes, ocorridos ao longo dos séculos XVIII e XIX, foram marcados pela coleta de histórias da cultura popular e enriquecimento desta cultura por meio de traduções de obras relevantes da cultura clássica, inglesa, francesa, italiana, espanhola, portuguesa e oriental.

\section{A relação de Lutero com Dolet e du Bellay}

Conforme demonstraremos a seguir, tal como Dolet, Martinho Lutero sentiu a necessidade de estabelecer balizas para a tradução que fizessem com que ela se submetesse às normas, ainda que escassas, que norteavam sua língua materna a partir do momento em que se pôs a traduzir a Bíblia e, tal como du Bellay, logo percebeu que a normatização do processo de tradução se define mais como uma questão de política linguística do que uma questão de estética. Aliás, Lutero parece seguir a risca seu conselho segundo o qual o tradutor deve priorizar a estética da língua para a qual traduz, evitando, portanto, imitar as formas clássicas consagradas ao traduzir.

Embora Lutero não tenha criado o Hochdeutsch (alemão padrão), sua tradução de partes da Bíblia influenciou profundamente a formação da língua nacional alemã uma vez que sua tradução acabou funcionando como padrão de avaliação no desenvolvimento da língua nacional alemã (cf. DELISLE e WOODSWORTH, 1995, p. 50). Ela também exerceu 
influência sobre a formação de uma cultura tipicamente germânica, que acabaria transformando a cultura ocidental por meio da expansão do protestantismo. A novidade por ela apresentada se encontra não só na padronização da língua, mas no uso desta língua para expressar ideias revolucionárias no interior do universo cristão - tanto que sua tradução foi severamente atacada pelos "papistas" (termo empregado por Lutero para denominar seus opositores).

O pedido de explicação sobre a introdução da palavra allein (só) em um versículo bíblico feito por um tal "honorável e distinto N." (cf. LUTERO, 2006, p. 95) toca diretamente no ponto de confluência entre questões linguísticas e dogmáticas da Bíblia de Lutero, proporcionando-lhe ensejo para reafirmar um dos principais dogmas que marcam a diferença entre o catolicismo e o protestantismo - a salvação pela fé - e apresentar seus métodos e concepções de tradução.

Do mesmo modo, eu sabia muito bem que em Romanos 3 não havia a palavra solum no texto latino ou grego, e não precisavam me ensinar isso os papistas. É verdade, estas quatro letras $s$ - $o$ - $l$ - $a$, que as cabeças de asno admiram como as vacas a uma nova porteira, não estão no texto. Eles não vêem que isso corresponde perfeitamente ao sentido do texto, e, quando se quer traduzir com clareza e consistência em alemão, deve estar presente, porque eu quis falar em alemão, não em latim nem em grego, quando me propus falar em alemão ao traduzir. Isso, porém, é propriedade de nossa língua alemã, que, quando usada para tratar de duas coisas, das quais uma é afirmada e outra negada, necessita da palavra sollum-allein, acompanhando a palavra nicht ou kein [não, nenhum]. Assim, por exemplo, quando se diz: Der Baur bringt allein Korn, und kein Geld [O camponês traz somente grãos e nenhum dinheiro]. Nein, ich habe wahrlich jetzt nicht Geld, sondern allein Korn [Não, realmente agora não tenho dinheiro, mas apenas grãos]. Ich habe allein gegessen und noch nicht getrunken [Eu somente comi e ainda não bebi]. Hast du allein geschrieben und nicht durchgelesen? [Apenas escreveste e não leste?] E inúmeras formas semelhantes no uso diário.

Se tanto a língua latina como a grega não procedem desta forma em todos estes idiomatismos, a alemã procede assim, e é de sua propriedade usar a palavra allein a fim de que a palavra nicht ou kein resulte mais plena e clara. Pois, embora eu também possa dizer: Der Baur bringt Korn und kein Geld, assim dita, a expressão Kein Geld não soa tão plena e clara como quando eu digo: Der Baur bringt allein Korn und kein Geld [O camponês trouxe somente grãos e nenhum dinheiro]: aqui a palavra allein ajuda a palavra kein a produzir uma fala plena, alemã, clara. Pois não se tem que perguntar às letras na língua latina como se deve falar alemão, como fazem os asnos, mas, sim, há que se perguntar à mãe em casa, às crianças na rua, ao homem comum no mercado, e olhá-los na boca para ver como falam e depois traduzir; aí então eles vão entender e perceber que se está falando em alemão com eles. (LUTERO, 2006, p. 103-105)

A introdução do termo allein, que Lutero afirma se dever a uma das características da língua alemã, deve-se, concomitantemente, ao sentido que ele atribuiu ao que estava escrito no texto de partida (o Novo Testamento em grego) -, à leitura que ele fez e que desencadeou o 
protesto contra o dogma católico da salvação pelas obras.

A princípio, Lutero era um pregador católico como todos os demais e recebeu a mesma formação que as demais autoridades católicas. Porém lhe interessava disponibilizar as Sagradas Escrituras para os fiéis que frequentavam as paróquias, para que cada um pudesse fazer a sua própria leitura - a pretendida pela burguesia local, junto à qual Lutero se colocava, deixando de ser, a partir de então, um pregador como os demais. Com este objetivo, aprofundou-se nos estudos de grego e hebraico, além do latim, e se pôs a traduzir partes da Bíblia a partir dos textos anteriores à Vulgata ${ }^{i v}$. Lutero foi a sua fonte e, compelido pelo Zeitgeist - marcado por conflitos sociais que exigiam reformas que só chegariam ao âmbito social se atingissem o âmbito religioso, já que há séculos a política e a religião eram indissolúveis -, atribuiu-lhe sentidos diferentes daqueles então intermediados pela versão latina. Daí a necessidade de uma nova tradução da Bíblia para o alemão que contemplasse simultaneamente o modo de expressão da burguesia alemã e suas ideias anti-catolicismo.

De fato, antes de Lutero e sua Bíblia, já existia uma língua alemã padronizada, graças, também, a traduções da Bíblia - a tradução do Novo Testamento feita no Mosteiro de Fulda por volta do ano 820 a partir do texto latino de Ticiano datado do século II; a tradução do Livro dos Evangelhos feita por Otfried von Weissenburg e completada em alto alemão antigo por volta de 870 e, por fim, a tradução dos Salmos feita por Notker, o Alemão, por volta do ano 1000 cf. (DELISLE e WOODSWORTH, 1995, p. 45). A primeira tradução completa da Bíblia para o alemão data de 1475. As diferenças entre estas traduções e a de Lutero se encontram na fonte utilizada - as primeiras se basearam na Vulgata, enquanto as de Lutero remontam aos originais em grego e hebraico -; ao alemão utilizado - cada uma foi escrita na língua falada pela classe de maior prestígio à respectiva época - e ao conteúdo disseminado cada qual expressou as ideias e anseios da classe ascendente no momento da tradução. Os resultados da tradução de Lutero foram a Reforma Protestante, a reação antirreformista, a padronização do alemão falado pela burguesia da região centro-oriental do Império Germânico, em ascensão naquele momento, bem como o fortalecimento de suas ideias. Como esta classe dominou o cenário a partir de então, seu Hochdeutsch - tal como suas ideias suplantou o anterior.

Em primeiro lugar, se eu doutor Lutero, tivesse podido enganar-me de que todos os papistas juntos fossem tão hábeis a ponto de saberem traduzir bem e corretamente um capítulo da Escritura, então teria sido muito humilde e lhes teria solicitado ajuda e assistência para a tradução em alemão do Novo Testamento. Mas como eu sabia e ainda posso ver que nenhum deles sabe realmente como se deve traduzir ou falar em 
alemão, poupei-me a mim e a eles um tal esforço. No entanto, percebe-se bem que eles aprendem a falar e a escrever em alemão a partir da minha tradução e de meu alemão, e roubam-me em muito minha língua, que até então pouco conheciam; porém não me agradecem por isso, mas preferem a utilizar contra mim. Contudo, é com prazer que lhes proporciono isso, pois me agrada estar ensinando a falar a meus discípulos ingratos, que ademais são meus inimigos. (...) Contudo, gostaria de ver um papista que se sobressaísse e traduzisse algo de uma das Epístolas de São Paulo ou de um profeta, desde que para isso não se servisse do alemão e da tradução de Lutero; então veríamos um alemão ou um tradução elegante, bela, admirável. Pois já vimos o embusteiro de Dresden, que se apropriou de meu Novo Testamento (não quero mais mencionar seu nome em meus livros; ademais, ele também tem agora seus juízes e é bem conhecido). Ele confessa que meu alemão é suave e bom; percebeu que não podia melhorá-lo e quis destroçá-lo. Assim, tomou meu Novo Testamento, quase palavra por palavra, da forma como eu o compus, retirou meu prefácio, comentários e meu nome, e acrescentou seu nome, prefácio e comentários, e desta forma vendeu meu Novo Testamento com seu nome. (LUTERO, 2006, p. 95 e 97-99)

Datam do século XVI as primeiras gramáticas de língua alemã, dentre as quais se encontram Grammatica germanicae linguae ex Bibliis Lutheri germanicis et aliis eius libris collecta (Gramática da língua alemã baseada na Bíblia de Lutero e em suas outras obras conhecidas), de Johannes Clajus (1535-1592) e Ein Teütsche Grammatica (Uma gramática teutônica), (1534), de Valentin Ickelsamer. Daí o alemão padrão ser visto como fruto da tradução de Lutero - o que as coloca em relevo como meio de fixação da língua e produção e disseminação de cultura no Império Germânico.

Se a Bíblia de Lutero pôde servir de base para a língua alemã, foi não apenas porque empregou a língua da classe em ascensão, mas também porque as ideias que difundia estavam historicamente conectadas com as ideias correntes à época, demarcando uma conjunção histórica e cultural que rompe com o que havia antes. É neste sentido que Antoine Berman afirma que há um período pré-Lutero e outro, pós-Lutero, que não se restringiria aos aspectos político e religioso, mas se entenderia ao aspecto literário (cf. BERMAN, 1992, p. 27) e, acrescentemos, linguístico.

Assim, pode-se considerar que o processo de formação da língua alemã hoje utilizada - e da cultura - estendeu-se por mil anos, sempre se assentando na assimilação de outras culturas, traduzidas convenientemente para manifestar os interesses locais momentâneos.

Como se pode perceber, dentre tantas diferenças entre a tradição tradutória francesa e a germânica, o contexto francês e germânico no século XVI possibilitou que 


\section{A planta exótica de Schleiermacher}

No início do século XIX, a Teoria Relativista da Língua, de Wilhelm von Humboldt (1767-1835), afirmava que a língua influencia a forma de pensar, ou seja, o pensamento depende da língua em que é expresso. Daí a necessidade premente de se fixar a língua padrão germânica. Além disso, a existência de uma língua nacional germânica padronizada era importante para o estabelecimento da identidade alemã, considerando-se que a língua define a identidade de uma comunidade, constituindo-se no principal elemento definidor de identidade cultural - somada aos demais vínculos que criam coesão no interior de uma nação, a língua acaba por constituir a base para a diferenciação desta nação em relação a outras e, embora a língua, por si só, não congregue condições suficientes para a autonomia de uma nação, sua existência é fundamental para a constituição da nação.

De fato, havia uma relação direta entre a impossibilidade de se constituir um estadonação germânico e o atraso, em relação às demais nações da Europa Ocidental, na sistematização da língua e formação de um cânone literário no interior o Império Germânico, uma vez que a noção de nação pressupõe a existência de um grupo de indivíduos que compartilham elementos culturais, dentre os quais a língua - e a literatura por meio da qual ela se estabelece - destaca-se, e a noção de estado, por um lado, alia-se à de país, ou seja, implica, entre vários elementos, a existência de um território delimitado geograficamente, e, por outro, pressupõe a presença de governo próprio, leis que regulamentem as atividades de seus cidadãos e forças armadas para defender o território, seu governo e seu povo. Daí a relação de interdependência entre as noções de estado, nação, pátria, língua e literatura.

Neste contexto, diferentemente do que até então se preconizara na França, os germânicos perceberam que era melhor não adaptar o texto de partida à língua e cultura de chegada, mantendo-se seu caráter estrangeiro, a fim de enriquecer a cultura de chegada com novos conceitos e novo vocabulário, que era adaptado às regras da ortografia germânica. Friedrich Schleiermacher afirmava que a vocação germânica para a tradução fora determinada pela própria necessidade interna - a necessidade de criar uma cultura germânica aplanadora das diferenças internas que, para tanto, valia-se da apropriação do que lhe era estrangeiro. Explicando-se, ele estabelece analogia entre a necessidade do cultivo de plantas exóticas para tornar mais rico e fecundo um solo e a necessidade de contato da língua-pátria com elementos estrangeiros para seu florescimento e desenvolvimento. Ele mesmo já se referira à sua língua como “nosso pobre alemão" (1813/2007, p. 256). 
Mas as inovações linguísticas, advertia Schleiermacher, deveriam ficar restritas ao âmbito da tradução. Ele acreditava que aqueles que as usassem inadequadamente encontrariam poucos seguidores. Além disso, confiava que, a longo prazo, o próprio "processo assimilador da língua" se incumbiria de eliminar o que não fosse adequado a sua natureza (cf. ibid., p. 264) - a partir de 1801, o Wörterbuch zur Erklärung und Verdeutschung der unserer Sprache aufgedrungenen fremden Ausdrücke nach der Verdeutschung dieser Fremdwörter (Dicionário para explicação e germanização de nossa língua premida por expressões estrangeiras de acordo com a germanização destas palavras estrangeiras; tradução minha), de Joachin Heinrich Campe, passaria a auxiliar na tarefa de "assimilação do estrangeiro".

Ao lado da política de germanização dos termos estrangeiros que se encontravam em uso, a aceitação e adaptação do vocabulário estrangeiro novo e a criação de termos para expressar conceitos novos à cultura germânica advindos de outras culturas por meio da tradução foram responsáveis pela enorme quantidade de neologismos registrados em língua germânica nos séculos XVIII e XIX. Tal contexto teria levado Johann Wolfgang von Goethe a 100 expressar a seguinte máxima: “A força de uma língua não se encontra no fato de ela rejeitar o estrangeiro, mas sim em devorá-lo!” (apud. NECKER, 1907, p. 207, tradução minha.).

Consecutivamente, tornava-se dominante o interesse pela literatura universal com o objetivo de ampliar a cultura germânica - daí a importância da tradução, que, longe de ser concebida como ameaça, tornara-se fonte de enriquecimento: "De fato, de quais línguas não temos nós os melhores trabalhos nas mais eminentes traduções?", perguntaria Goethe $(1827 / 1993)$.

A tradução, então, chega a ser vista como instrumento de sujeição de outros povos à língua alemã que começava a se consolidar:

\footnotetext{
Independentemente de nossa produção, nós já atingimos um elevado patamar cultural (Bildung) graças à completa apropriação do que nos é estrangeiro. Logo outras nações terão que aprender alemão, pois perceberão que deste modo podem conservar em grande quantidade o aprendizado de quase todas as outras línguas. (GOETHE, 1827/1993.)
}

Como a literatura disponível em língua alemã nos séculos XVIII e XIX resultava, em grande parte, de tradução, ela se inclina a se notabilizar como repositório da literatura mundial, como bem o notara Goethe, demonstrando sua tendência a se constituir pela assimilação do que lhe era estrangeiro. Neste contexto, Goethe passou a usar o termo 
Weltliteratur (literatura mundial) com a acepção de obras literárias que ultrapassam as fronteiras nacionais e regionais, tornando-se significativas para a Weltbevölkerung (população mundial). Usado pela primeira vez por Christoph Martin Wieland, Weltliteratur tinha o sentido de literatura para o homme du monde ("homem do mundo" ou, em alemão, Weltmann) e com acepção comparável à de Weltkulturerbegeführt (patrimônio mundial), a partir de 1827, quando passou a ser empregado por Goethe, Weltliteratur assumiu a acepção de literatura criada a partir de um espírito cosmopolita, supra-nacional. Assim, seu caráter cosmopolita lhe seria atribuído não em virtude do público a que se destina, como o concebia Wieland, mas, sim, em virtude do espírito cosmopolita do próprio autor. Esta literatura mundial, acolhida pelos povos germânicos, serviria para enriquecer a cultura nacional então em formação (Bildung) e contribuiria para a constituição da nacionalidade alemã (Deutschheit) - causa à qual se dedicaram tanto Goethe quanto Wieland enquanto integrantes da primeira geração pós-Guerra dos Trinta Anos que desenvolveu um olhar crítico sobre a dominação francesa exercida no âmbito político e cultural dos estados germânicos e, por fim, no cotidiano de seus habitantes uma vez que a reconstrução do espaço físico, humano, cultural e intelectual dos estados germânicos no pós-guerra se dera sob o impacto dos valores e da cultura disseminados pela França.

Assim, no início do século XIX, quando Schleiermacher profere em Berlim sua célebre palestra "Über die verschiedenen Methoden des Übersetzens" (Os diferentes modos de traduzir), a língua e a literatura germânicas - bem como os indivíduos que as produziam e delas se serviam - já haviam se habituado a ser insufladas por línguas, gêneros literários, concepções, conceitos e experiências advindos de diferentes povos e culturas. Schlaeiermacher fala a uma plateia que dominava o a língua francesa e nela se expressava tão bem quanto em sua língua materna. $\mathrm{O}$ mesmo se aplica às cortes germânicas, que há muito tinham adotado a língua e a "etiqueta" (conjunto de "bons" hábitos sociais) francesas como instrumentos civilizatórios. Como reflexo, o povo, mesmo nos mais baixos estratos sociais, admirava tudo que fosse oriundo da França - língua, música, literatura, moda, costumes e valores. A partir de então, o caminho, que sempre estivera aberto para a literatura estrangeira, tornou-se mais largo, registrando-se uma verdadeira explosão na publicação de traduções em meados do século. Para se ter uma ideia, em 1850, dos 326 romances publicados em línguas germânicas, 164 (50\%) eram traduções - 72 títulos traduzidos do francês; 51, do inglês e, os 10 restantes, de outras línguas. Isso se explicaria, em parte, pela entrada no mercado de editoras que, ao invés de investir na publicação luxuosa e dispendiosa de obras para um 
público mais refinado, como as de Goethe e Schiller, dedicavam-se a publicar literatura popular em formatos de baixo custo - em sua maioria, traduções de romances populares franceses e ingleses - pelo simples fato de serem extremamente populares. Estas editoras eram chamadas pejorativamente de "Übersetzungsfabriken" (fábricas de tradução). Logo que leis internacionais de proteção aos direitos autorais passaram a vigorar, ainda na década de cinquenta, e a censura foi instituída na região de Leipzig, onde a maioria das "fábricas de tradução" se localizava, a publicação de títulos populares traduzidos foi reduzida, chegando a $25 \%$ dos 524 títulos de romances publicados em 1865 (cf. BACHLEITNER, 2009, p. 425427).

Até quase o final do século XVIII, a tradução fora uma atividade exclusiva de literatos - independentes do sistema comercial porquanto eram subvencionados pelo sistema eclesiástico ou por aristocratas. Foi apenas na passagem para o século XIX que a quantidade de tradutores provenientes de áreas diferentes da literária aumentou e os envolvidos com literatura eram, em geral, escritores de romances populares, escritores desprestigiados ou jornalistas. Nas décadas seguintes, a tradução passou a ser feita também por funcionários 102 públicos, professores e governantas, com vistas a incrementar seus proventos (cf. ibid, p. 428).

Imaginando-se tal cenário, em que as traduções precisavam agradar ao público para serem consumidas, como qualquer outra mercadoria, e em que os tradutores não tinham grande comprometimento com a atividade literária, é de se imaginar que as normas de tradução francesas, conforme ditadas por Du Bellay, tenham sido adotadas também em terras germânicas. De qualquer forma, algumas diferenças básicas entre as traduções praticadas pelos seguidores das "belles infidèles" e as praticadas pelos tradutores germânicos persistiam. Por exemplo, os franceses se dedicavam sobretudo a obras clássicas - greco-latinas - e as adaptavam não apenas para embelezá-las segundo os padrões franceses, mas também para expurgar os costumes que fossem de encontro aos comuns à sociedade composta por seu público leitor. Os germânicos, por sua vez, dedicavam-se a obras francesas e as eventuais alterações que processavam no enredo não visavam a excluir marcas de costumes diferentes dos de seus leitores; eram movidos mais por interesses relacionados a técnicas comerciais. Voltando-nos, agora, para o cenário anterior, percebemos que, desta miscelânea composta pelas obras colocadas à disposição dos leitores germânicos, homogeneizada pelo processo de assimilação, emergiria, na segunda metade do século XIX, a língua alemã padrão e a literatura alemã - englobando também a literatura popular traduzida em curso. Ambas fortes e 
diversificadas, porquanto originárias de um solo enriquecido e fertilizado pela "planta exótica" de que nos fala Schleiermacher. Emergiria, também, o Império Alemão.

\section{Conclusão}

Quanto às diferentes perspectivas sobre tradução apresentadas por autores e tradutores franceses e germânicos, percebemos que, na França, um estado-nação estabelecido desde o final da Guerra dos Cem Anos (1337-1453), a partir do século XVII não se reconhecia qualquer necessidade de se enriquecer a cultura local com culturas a ela estrangeiras. Ao contrário - enquanto centro cultural do Ocidente, na França, zelava-se para que nada “desvirtuasse" sua cultura. Daí a necessidade de adaptar a literatura estrangeira à sua própria durante o processo de tradução.

$\mathrm{Na}$ Alemanha, uma nação que passou por um longo período de gestação que se estendeu por séculos, a assimilação do estrangeiro era aconselhada e praticada com o propósito de se constituir uma cultura nacional que se tornaria esteio do novo estado-nação em que os estados germânicos se constituiriam a partir de 1871, quando emergem unificados da Guerra Franco-Prussiana. Além disso, o "acolhimento do estrangeiro", acreditava-se, levaria a língua alemã a ocupar a posição de língua franca. De fato, o processo de formação da língua alemã, hoje utilizada como língua nacional da Alemanha, Áustria e Suíça - e da cultura alemã - estendeu-se por mil anos, sempre se assentando na assimilação de outras culturas, traduzidas convenientemente para manifestar os interesses locais momentâneos.

Porém, nem sempre os intelectuais franceses e germânicos estiveram em polos opostos, como bem o demonstra a prática de tradução de Lutero e as concepções de tradução que subjazem a sua prática.

Considerando que a língua influencia o modo de pensar, conforme defendia Humboldt, percebemos que a proposta dos intelectuais germânicos do final do século XVIII e início do XIX de assimilação do estrangeiro via tradução vai além de dela se servirem como ato central de seu projeto de construção (Bildung) da germanidade (Deutschheit); dela se valem, também, como instrumento de "empoderamento" de sua língua, cultura e nação com vistas aos propósitos imperialistas que se apresentariam no século seguinte. 


\section{REFERÊNCIAS BIBLIOGRÁFICAS}

BACHLEITNER, N. A Proposal to Include Book History in Translation Studies Illustrated with German Translations of Scott and Flaubert. In: BITI, V. e LISKA, V. (Org.). Arcadia International Journal of Literary Culture - Internationale Zeitschrift für Literaturwissenschaft. Disponível em: 〈http://www.degruyter.com/view/j/arca>. Acesso em: $15 / 03 / 2015$.

BALLIU, C. Los traductores transparentes: historia de la traducción en Francia durante el período clásico. In: Revista Hyeronymus Complutensis, n. 1, 1995. Disponível em: <http://cvc.cervantes.es/lengua/hieronymus/pdf/01/01_009.pdf >. Acesso em: 10/03/2015.

BERMAN, A. The experience of the foreign: Culture and translation in romantic Germany. Nova Iorque: SUNY, 1992.

BRESSER-PEREIRA, L. C. Nação, estado e estado-nação. Disponível em: $<$ http://www.bresserpereira.org.br/papers/2008/08.21.Na\%C3\%A7\%C3\%A3o.Estado.EstadoNa\%C3\%A7\%C3\%A3o-Mar\%C3\%A7o18.pdf>. Acesso em: 01/09/2013.

DELISLE, J. e WOODSWORTH, J. Translators through history. Amsterdam: Jonh Benjamins Publishing Co, 1995.

104 ENGELS, F. 1888. Die Rolle der Gewalt in der Geschichte. Disponível em: <http://www.mlwerke.de/me/me21/me21_405.htm>. Acesso em: 30/09/2013.

GOETHE, J. W. Tagebuch 15. Januar 1827: An Schuchardt diktiert bezüglich auf französische und Weltliteratur. In: Goethe die letzten Jahre. Vol. II - vom 1. Januar 1823 bis zu seinem Tod. Bibliothek Deutscher Klassiker. Frankfurt am Main: Deutscher Klassiker Vergag, 1993.

HOBSBAWM, E. J. Nações e nacionalismo desde 1780. Tradução de Maris. Celia Paoli e Anna Maria Quirino. Rio de Janeiro: Paz e Terra, 1990.

LUTERO, M. "Sendbrief vom Dolmetschen (1530)". In FURLAN, Mauri (org. e trad.). Clássicos da teoria da tradução, Renascimento. Vol. 4. Florianópolis: UFSC/NUPLITT, 2006. p. 91-115.

MILTON, J. Tradução - teoria e prática. São Paulo: Martins Fontes, 1998.

NECKER, M. (editor). Maximen und Reflexionen von Goethe. Weimar: Verlag der Goethe Gesellschaft, 1907.

POPPI, C. Século XVII na França: Les Belles Infidèles, Racine e o modelo dos clássicos antigos. In: Non Plus, [S.1.], n. 3, 2013, p. 29-43. Disponível em: <http://www.revistas.usp.br/nonplus/article/view/49033>. Acesso em: 03/03/2015. doi: http://dx.doi.org/10.11606/issn.2316-3976.v2i3p29-43.

SCHLEIRMACHER, F. Über die verschiedenen Methoden des Übersetzens/Sobre os diferentes Métodos de Traduzir (trad. Margarete von Mühlen Poll, Celso R. Braida, Mauri Furlan). In: Revista Princípios, Vol. 14, № 21, 2007, p. 233-265. 
ZUBER, R. Les «Belles Infidèles » et la formation du goût classique : Perrot d'Ablancourt et Guez de Balzac. Paris : Armand Colin, 1995.

i O presente artigo resulta de pesquisa patrocinada pela Fundação de Amparo à Pesquisa do Estado de São Paulo (FAPESP) por meio da concessão de uma bolsa de pós-doutorado que vigorou entre 2011 e 2014. Seu conteúdo foi apresentado na comunicação "Por que as belles infidèles não podiam prosperar entre Goethe e os românticos germânicos...", no III Encontro "E por falar em tradução...", organizado pela área de Estudos da Tradução da Universidade de São Paulo (USP) e Universidade Estadual de Campinas (UNICAMP) que teve lugar no Instituto de Estudos da Linguagem da UNICAMP em outubro de 2014.

ii Vanete SANTANA-DEZMANN (anteriormente: Vanete Dutra Santana) - Bacharel (1996) e licenciada (1996) em Letras (Literatura Brasileira e Portuguesa e Língua Portuguesa/Francesa) pela Universidade de Campinas (Unicamp). Mestre (2002) e Doutora (2007) em Linguística Aplicada (Teorias de Tradução) pela mesma universidade. Pós-doutoranda da Universidade de São Paulo com bolsa da Fundação de Amparo à Pesquisa do Estado de São Paulo (FAPESP).

Site pessoal: http://www.vanete.de/429275566

Currículo Lattes Vanete Dutra Santana. Disponível em: http://lattes.cnpq.br/9397364746187279

iii Os conceitos de estado, nação e estado-nação aqui apresentados foram simplificados e baseados nas definições apresentadas por Bresser Pereira. Encontramos uma análise aprofundada sobre o tema em Nações $e$ Nacionalismo - desde 1780, de Eric J. Hobsbawm.

iv A tradução da Bíblia para o latim feita no século IV por São Jerônimo, também a partir do grego - para o Velho Testamento - e hebraico - para o Novo Testamento.

RECEBIDO EM: 24 de fevereiro de 2016

ACEITO EM: 28 de outubro de 2016

PUBLICADO EM: Dezembro de 2016 